\title{
Establishment and characterization of two human breast carcinoma cell lines by spontaneous immortalization: Discordance between Estrogen, Progesterone and HER2/neu receptors of breast carcinoma tissues with derived cell lines
}

Behnam Kamalidehghan ${ }^{1,2}$, Massoud Houshmand ${ }^{3,4}$, Fereydoun Kamalidehghan ${ }^{5}$, Narges Jafarzadeh ${ }^{1}$, Shahram Azari, ${ }^{6,7}$, Sharifah Noor Akmal ${ }^{8}$ and Rozita Rosli ${ }^{1,9^{*}}$

\begin{abstract}
Background: Breast cancer is one of the most common cancers among women throughout the world. Therefore, established cell lines are widely used as in vitro experimental models in cancer research.

Methods: Two continuous human breast cell lines, designated MBC1 and MBC2, were successfully established and characterized from invasive ductal breast carcinoma tissues of Malaysian patients. MBC1 and MBC2 have been characterized in terms of morphology analysis, population doubling time, clonogenic formation, wound healing assay, invasion assay, cell cycle, DNA profiling, fluorescence immunocytochemistry, Western blotting and karyotyping.
\end{abstract}

Results: MBC1 and MBC2 exhibited adherent monolayer epithelial morphology at a passage number of 150 . Receptor status of $\mathrm{MBC} 1$ and $\mathrm{MBC2}$ show $\left(\mathrm{ER}^{+}, \mathrm{PR}^{+}, \mathrm{HER} 2^{+}\right)$and $\left(\mathrm{ER}^{+}, \mathrm{PR}^{-}, \mathrm{HER} 2^{+}\right)$, respectively. These results are in discordance with histopathological studies of the tumoral tissues, which were triple negative and $\left(E R^{-}, \mathrm{PR}^{-}, \mathrm{HER} 2^{+}\right.$) for $\mathrm{MBC1}$ and $\mathrm{MBC2}$, respectively. Both cell lines were capable of growing in soft agar culture, which suggests their metastatic potential. The MBC1 and MBC2 metaphase spreads showed an abnormal karyotype, including hyperdiploidy and complex rearrangements with modes of 52-58 chromosomes per cell.

Conclusions: Loss or gain in secondary properties, deregulation and specific genetic changes possibly conferred receptor changes during the culturing of tumoral cells. Thus, we hypothesize that, among heterogenous tumoral cells, only a small minority of $\mathrm{ER}^{+} / \mathrm{PR}^{+} / \mathrm{HER}^{+}$and $\mathrm{ER}^{+} / \mathrm{PR}^{-} / \mathrm{HER}^{+}$cells with lower energy metabolism might survive and adjust easily to in vitro conditions. These cell lines will pave the way for new perspectives in genetic and biological investigations, drug resistance and chemotherapy studies, and would serve as prototype models in Malaysian breast carcinogenesis investigations.

Keywords: Malaysian breast cell lines, Estrogen (ER), Progesterone (PR) and HER2/neu, Clonogenic assay, Invasive ductal breast carcinoma tissues, DNA profiling

\footnotetext{
*Correspondence: rozita@medic.upm.edu.my

${ }^{1}$ Genetic Medicine Research Centre, Faculty of Medicine and Health Sciences,

Universiti Putra Malaysia UPM Serdang, Selangor 43400, Malaysia

${ }^{9}$ UPM-MAKNA Cancer Research Laboratory, Institute of Bioscience, Universiti

Putra Malaysia UPM Serdang, Selangor 43400, Malaysia

Full list of author information is available at the end of the article
} 


\section{Introduction}

Breast cancer is the most common cancer among women throughout the world. The number of newlydiagnosed cases in 2008 was approximately 1.38 million, and the number of deaths was more than 460,000 worldwide [1].

Breast cancer is the most common cancer among Malaysian women. The peak age for cancer cases among the three major ethnic groups, namely Malay, Chinese and Indian was between 40 to 49 years [2]. Malay women presented larger tumours, in which $50 \%$ to $60 \%$ were at the later stages ( 3 and 4 ), compared to other ethnic groups [3].

Though advances in breast cancer detection and treatment have contributed to improving the rate of survival, mortality rates remains significantly high. The establishment of breast cancer cell lines is an important tool to understand biological processes involved in this disease, as well as the identification of potential therapeutic targets [4].

Cell lines are used to determine key initiation and progression factors in order to better understand a disease. They are also used to predict the efficacy of novel therapeutic compounds. However, the cell lines currently used for breast cancer are mostly derived from Caucasians or African-Americans. Though breast cancer cell lines are easy to handle and replaced from frozen stocks, they are prone to genotypic and phenotypic drifts during consecutive cultures $[5,6]$.

Most in vitro studies using a few well-characterized breast cancer cell lines such as MCF-7, MDA-MB-231, T-47D and ZR-75-30 have been established for over 30 years. These cell lines were derived from tumor metastases especially aspirate or pleural effusions but not from primary breast tumors [7-9].

The main objective of this study was to establish and characterize two new immortalised Malaysian breast cancer cell lines, which are derived from two fresh primary invasive ductal breast carcinoma tissues.

\section{Materials and Methods}

\section{Cancer cell isolation and cell culture}

Ethics approval and patient informed consent including consent to participate in the study and consent to publish was obtained for the present study in accordance to the Universiti Kebangsaan Malaysia (UKM) Research and Medical Ethics Committee (Approval No. FF-166-2004).

Two invasive ductal breast carcinoma tissues, one from a Malay patient with triple negative (ER', $\mathrm{PR}^{-}$, HER2 ${ }^{-}$) tumor and another from a Chinese patient with $\left(\mathrm{ER}^{-}, \mathrm{PR}^{-}, \mathrm{HER} 2^{+}\right)$tumor, were collected from Hospital Universiti Kebangsaan Malaysia (HUKM). After surgical removal, a portion of the primary breast tissues were immediately placed in FBS-free DMEM (Sigma-Aldrich,
USA) and were minced and scraped to isolate cancer cells, in accordance to the manufacturer's instructions of the Cancer Cell Isolation Kit (Panomics, USA). The cells were cultured in six-well culture plates supplemented with 10\% FBS (Sigma-Aldrich, USA) and $3.7 \mathrm{~g} / \mathrm{L}$ sodium bicarbonate (Sigma-Aldrich, USA) with a $\mathrm{pH}$ of 7.4 in a humidified incubator with $5 \% \mathrm{CO}_{2}$ at $37^{\circ} \mathrm{C}$ (IR Sensor, Sanyo). Both cell lines were subcultured and then used to determine the characteristics of the established cell lines.

\section{Epithelial phenotype}

The purity of the epithelial phenotype was confirmed by staining with a pan-cytokeratin antiserum (FITC conjugate; Dako, Denmark).

\section{Mycoplasma examination}

Both $\mathrm{MBC} 1$ and $\mathrm{MBC} 2$ cell lines were cultured on coverslips in 6-well plates and incubated overnight until confluent. The coverslips were washed with PBS and fixed with a fixative; then stained with DAPI and kept in the dark place for $10 \mathrm{~min}$. After that, the coverslips were washed with distilled water and dried to detect mycoplasma using a fluorescence microscope (Leica, Germany).

\section{Population doubling time (PDT)}

A total of $2 \times 10^{5}$ cells $/ \mathrm{ml}$ of MBC1 and MBC2 cell lines at passage 30 were cultivated for a period of 3 days (24, 48 and $72 \mathrm{hrs}$ ). Cell numbers were determined every 24 hrs using a Neubauer improved haematocytometer (Sigma-Aldrich, USA) and cell numbers were counted in triplicate. Population doubling time was calculated using an online algorithm software provided at http://www. doubling-time.com.

\section{Clonogenic assay}

A two-layer technique was used, with a base layer consisting of $1 \%$ agar (BST TechLab, Malaysia), and a second layer containing cells with $0.7 \%$ agar. Briefly, equal volumes of the base agar (melted in a microwave oven and cooled to $40^{\circ} \mathrm{C}$ in a water bath) containing $1 \%$ agar along with 2X DMEM containing 20\% FCS were mixed to obtain $0.5 \%$ agar and $1 \mathrm{X}$ DMEM with $10 \%$ FCS. Subsequently, $1.5 \mathrm{ml}$ of the mixed solution $s$ was added to a petri dish $(35 \mathrm{~mm})$. The second layer, $3 \mathrm{ml}$ of 2X DMEM (20\% FCS) and $3 \mathrm{ml}$ of $0.7 \%$ agar were added to a centrifuge falcon tube and mixed gently. The cells were trypsinised and counted to a ratio of $5 \times 10^{3}$ cells per plate. After that, $1.5 \mathrm{ml}$ was added to each petri dish $(35 \mathrm{~mm})$ that was covered with the earlier agar base. The plates were incubated for 14 days at $37^{\circ} \mathrm{C}$ and $5 \% \mathrm{CO}_{2}$. Plates were then stained with $0.5 \mathrm{ml}$ of $0.005 \%$ crystal violet for $2 \mathrm{hrs}$ and colonies were counted using an inverted microscope Nikon Eclipse TS100 camera (Nikon DSFi1). The cloning efficiency (CE) was calculated as the 
number of colonies divided by the number of cells added to each plate.

\section{Wound healing assay (Migration assay)}

The cell lines were seeded in 6-well plates until the cells reach confluence. Then, a straight scratch was made using a yellow plastic pipette tip. Next, the plates were rinsed twice with PBS to remove floating cells. The underside of the dish was marked to indicate the wounded area where the initial photos were taken, which allowed the imaging of both wound edges using the 10X objective at $6,12,18,23$ and 25 hrs. Subsequential images were periodically recorded with an inverted phase microscope Nikon Eclipse TS100 camera (Nikon DS-Fi1). The migration of cells across the wounds was expressed as the percentage of wound closure: Wound closure $(\%)=\left[\left(\right.\right.$ Initial area $\mathrm{a}_{\mathrm{to}}-$ Final $\operatorname{area}_{\mathrm{tf}} / /$ Initial $\left.\mathrm{area}_{\mathrm{to}}\right] \times 100$.

\section{Matrigel invasion assay}

The in vitro invasion assay was performed using BioCoat Matrigel invasion assay system (BD Biosciences, USA), according to the manufacturer's instructions. Invaded cells were counted under a light microscope Nikon E600. The percentage of the invasion capability of the cell lines was calculated as follows: Invasion (\%) =Number of cells attached to the lower side of the filter/ total number of cells $\times 100$.

\section{Genomic DNA preparation and PCR amplification}

The genomic DNA from the cell lines was extracted using a Qiagen kit (QIAamp DNA Mini Kit, Germany), according to the manufacturer's instructions. DNA yields were quantified by Nano-drop (Thermo Nanodrop 2000) and $1 \%$ agarose (Roche, Germany) gel electrophoresis to determine the integrity of extracted DNA. The details of the primer pairs for amplification of all 13 CODIS STR alleles and Amelogenin in this study was assessed according to the protocol previously described [10].

\section{Non-denaturing polyacrylamide gel electrophoresis}

To achieve adequate resolution for the separation of the different STRs and Amelogenin alleles, large nondenaturing $10 \%$ polyacrylamide gels were used, as explained previously [10].

\section{Western blotting}

After protein extraction from the cell lines using protein extraction buffer (Pierce, USA), $30 \mu \mathrm{g}$ of proteins were separated by $12 \%$ SDS-PAGE ( $25 \mathrm{~mA} ; 2$ hrs). Proteins were transferred to PVDF (Pierce, USA) membranes using a Trans-Blot SD Semi-Dry Transfer Cell (Bio-Rad, USA) at $15 \mathrm{~V}, 95 \mathrm{~mA}$, for 1 hour. The PVDF membrane was blocked using Blocker ${ }^{\mathrm{TM}}$ Casein (Pierce, USA) for 1 hour at room temperature and then washed twice using TBST. The membranes were then incubated at $4^{\circ} \mathrm{C}$ overnight with primary antibodies, estrogen mouse monoclonal antibody (1:1000; DAKO, Denmark), progesterone mouse monoclonal antibody (1:1000; DAKO, Denmark), HER2 rabbit polyclonal antibody (1:500; DAKO, Denmark) and $\beta$-actin mouse monoclonal antibody (1:10000; DAKO, Denmark). The membranes were then incubated for $1 \mathrm{hr}$ at room temperature with goat anti-mouse and goat anti-rabbit secondary antibodies conjugated with alkaline phosphatase (i-DNA, USA) at a ratio of 1:1000 and then washed twice with TBST for 10 minutes three times on an orbital shaker. Then, blots were developed using the BCIP/NBT (Santa Cruz, USA) solution for a period of 5-30 minutes to detect the target protein band as a precipitated dark blue colour.

\section{Fluorescence immunocytochemistry of ER, PR and HER2}

$5 \times 10^{3}$ cells were seeded on coverslips in 6-well plates and incubated at $37^{\circ} \mathrm{C}$ in a humidified $\mathrm{CO}_{2}$ incubator. The cells were washed with PBS and incubated with 700 $\mu \mathrm{L}$ of $4 \%(\mathrm{v} / \mathrm{v})$ paraformaldehyde for $15 \mathrm{~min}$ at RT and then the cells were washed with PBS. Then, $700 \mu \mathrm{l}$ of antigen retrieval buffer $(100 \mathrm{mM}$ Tris, $5 \%(\mathrm{w} / \mathrm{v})$ urea, $\mathrm{pH}$ 9.5) was added to the wells for $10 \mathrm{~min}$ at $95^{\circ} \mathrm{C}$ and washed twice with PBS. Next, $700 \mu \mathrm{l}$ of permeabilisation buffer (0.1\% Triton X-100 in PBS) was added to the cells for 15 minutes at RT and then washed with PBS. The Blocking buffer (2\% BSA) was added for $2 \mathrm{hrs}$ and then washed with PBS. The primary antibodies (DAKO, Denmark) for estrogen, progesterone and HER2 was added at a ratio of 1:35, 1:50 and 1:250, respectively and left overnight, followed by washing with PBS. The goat anti-mouse FITC secondary antibody (i-DNA, USA) for ER and PR and the goat anti-rabbit FITC secondary antibody (i-DNA, USA) for HER2 were added for 1 hour at $\mathrm{RT}$, incubated away from light and then washed twice with PBS. Finally, mounting buffer (Glycerol: PBS; 9:1) was used to mount coverslips on the slides to visualise ER, PR and HER2 expression under a fluorescent microscope (Leica, Germany).

\section{Determination of S-phase by the PI}

Both cell lines were harvested and washed with 1X PBS; then, the cell pellets were fixed with pre-stored $90 \%$ ethanol at $-20^{\circ} \mathrm{C}$ and were then incubated overnight at $-20^{\circ} \mathrm{C}(0.5 \mathrm{ml})$. After incubation, cells were spun down at $800 \mathrm{rpm}$ for $5 \mathrm{~min}$. The supernatant was carefully discarded and the cells were resuspended by tapping until the pellet was fully dissolved. The cells were then washed in 1X PBS at $2000 \mathrm{rpm}$ for $5 \mathrm{~min}$. Again, supernatant was carefully discarded and the cells resuspended in $450 \mu \mathrm{l}$ of pre-warmed 1X PBS and $25 \mu \mathrm{l}$ of $10 \mathrm{mg} / \mathrm{ml}$ RNase at $37^{\circ} \mathrm{C}$. After that, $50 \mu \mathrm{l} \mathrm{of} 1 \mathrm{mg} / \mathrm{ml}$ propidium 
iodide solution (PI) (Sigma-Aldrich, USA) was added and mixed well in an incubator for $30 \mathrm{~min}$ at $37^{\circ} \mathrm{C}$. Finally, the stained samples were analysed using a FACS LSR FORTESSA flowcytometer which excites at $488 \mathrm{~nm}$. The proliferation index (P.I.) was calculated by following formula P.I. $=\left(S+G_{2} M\right) / G_{0} G_{1}$.

\section{Metaphase spread}

The cell lines were seeded in DMEM medium to reach $70 \%$ confluent. Then, $50 \mu \mathrm{l}$ of $10 \mu \mathrm{g} / \mathrm{ml}$ colcemid (GIBCO, USA) was added to the culture medium in a humidified incubator with $5 \% \mathrm{CO}_{2}$ at $37^{\circ} \mathrm{C}$ for $2 \mathrm{hrs}$. Both media and trypsinised cells were centrifuged at $900 \mathrm{rpm}$ for $5 \mathrm{~min}$. The supernatant was decanted and the pellet was dispersed by tapping gently. Five $\mathrm{ml}$ of pre-warmed hypotonic solution $(0.4 \% \mathrm{KCl}$ and $0.4 \%$ Sodium Citrate; $1: 1)$ were added drop by drop and incubated at $37^{\circ} \mathrm{C}$ for 15 min. Ten drops of fresh cold fixative methanol (Merck, Germany) and acetic acid (Merck, Germany) with a ratio of 3:1 were added while gently mixing. The tube was placed on ice for $15 \mathrm{~min}$ and centrifuged at $1000 \mathrm{rpm}$ for $5 \mathrm{~min}$. The supernatant was discarded and the pellet was re-washed with $5 \mathrm{ml}$ fixative. After that, the supernatant was decanted and $200 \mu \mathrm{l}$ of fixative was added. Next, a maximum of 3 drops of the suspended cells were dropped carefully from a height of approximately 0.5 meters onto the slide, and left at room temperature overnight to dry. The slides were stained with Giemsa (GIBCO, USA) working solution for 3-5 min and rinsed with distilled water. The slides were air-dried and then analysed.

\section{Statistical analysis}

Analyses were performed using the Statistical Analysis System (SAS Institute 2003). The data were presented as mean \pm standard deviation. It was analysed using the ANOVA procedure of SAS. Significant differences were further separated using Duncan's multiple range test. Differences with a value of $\mathrm{p}<0.05$ were considered to be statistically significant.

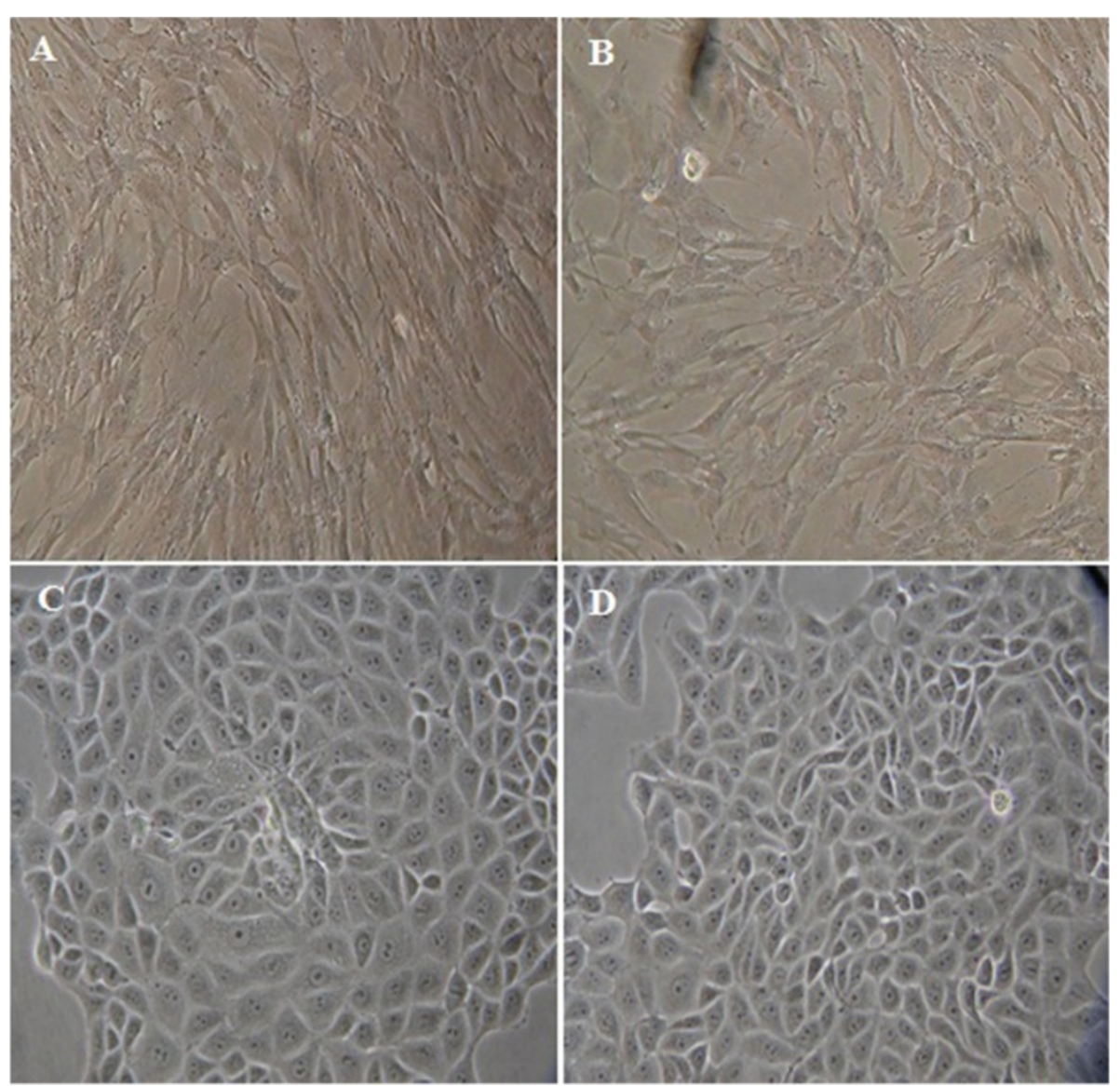

Figure 1 Morphology of the MBC1 and MBC2 Cell Lines. Panels (A) and (B) represent breast cancer MBC1-PN-2 and MBC2-PN-2, respectively; panels (C) and (D) represent breast cancer MBC1-PN-125 and MBC2-PN-85, respectively. Magnification, 40X; PN: passage number. 


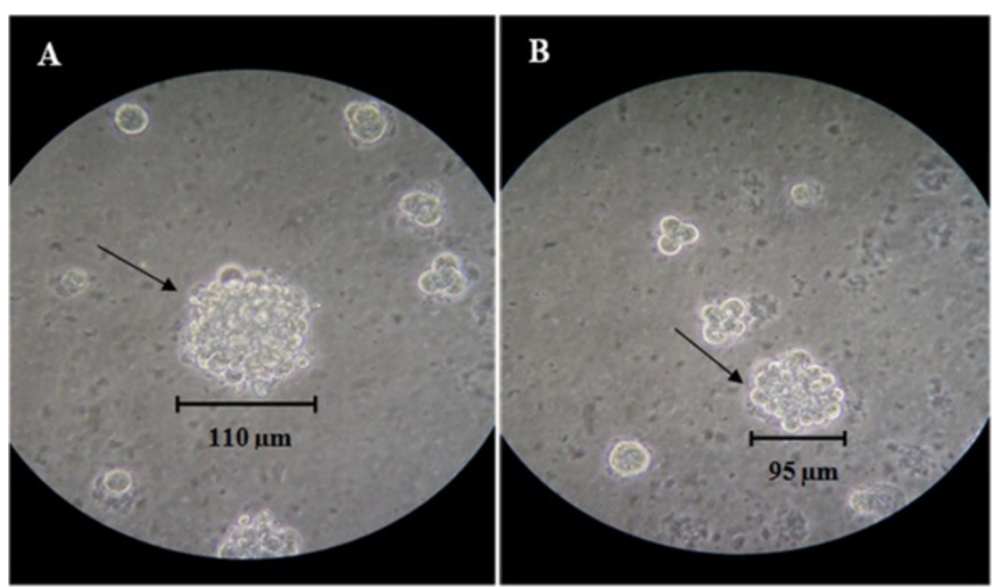

Figure 2 Soft-agar Colony Formation Assay (Clonogenic Assay) of the MBC1 and MBC2 Cell Lines at 14 Days after Seeding. Panels (A) and (B) represent MBC1 and MBC2 cell lines, respectively. Magnification, 10X.

\section{Results}

\section{Histopathology study}

Histological examination of the breast tissues showed that ER, PR and HER2/neu status of tumoral tissue for MBC1 was ER', $\mathrm{PR}^{-}$and HER2- (Triple negative), while for $\mathrm{MBC} 2$ was $\mathrm{ER}^{-}, \mathrm{PR}^{-}$and HER2 ${ }^{+}$(Data not shown).

\section{Morphology and culture of primary breast cell lines}

The population doubling time (PDT) of the first passage for the $\mathrm{MBC} 1$ and $\mathrm{MBC} 2$ was approximately 30 days after the initiation of culture. The morphology (Figure 1) of the two established human breast cell lines and the purity of the epithelial cells (data not shown) of the $\mathrm{MBC} 1$ and MBC2 human breast cell lines were determined. The growth medium for both $\mathrm{MBC} 1$ and $\mathrm{MBC} 2$ consisted of DMEM supplemented with $10 \%$ FBS and kept in a humidified incubator with $5 \% \mathrm{CO}_{2}$ at $37^{\circ} \mathrm{C}$. Cells were maintained in culture until passages 150, and then kept in liquid nitrogen. None of these established cell lines exhibited any signs of senescence and they were therefore considered immortalized. No sign of contamination, such as mycoplasma, fungi, or bacteria was observed.

\section{Clonogenic assay}

The MBC1 and $\mathrm{MBC} 2$ cell lines were able to produce colonies on the plate with similar cloning efficiencies (CE) of $1.074 \%$ and $1.048 \%$, respectively (Figure 2). Both $\mathrm{MBC} 1$ and $\mathrm{MBC} 2$ cell lines produced a colony size of approximately $95-110 \mu \mathrm{m}$ in diameter after 14 days on the soft agar. The cells also showed no significant difference $(p>0.05)$ in the colony formation rate (Figure 3 ).

\section{Wound healing assay (Migration assay)}

The migration of $\mathrm{MBC} 1$ and $\mathrm{MBC} 2$ cell lines across the wounds was calculated as a percentage of wound closure.
The growth rates of wound-healing assays for MCF-7 and MBC2 showed the highest and lowest growth rates in vitro wound-healing assays, respectively (Figure 4A, B).

\section{Matrigel invasion assay}

The invasion percentage of $\mathrm{MBC} 1, \mathrm{MBC} 2$ and MCF-7 were $0.110 \%, 0.040 \%$ and $0.116 \%$, respectively (Figure $5, \mathrm{~A}-\mathrm{F}$ ). No significant differences were observed between $\mathrm{MBC1}$ and MCF-7 ( $p>0.05)$, indicating the similar invasion ability of the MBC1 and MCF-7 cell lines to migrate through and adhere to the lower side of the filter in vitro condition. However, $\mathrm{MBC} 2$ demonstrated lower invasion activity compared to the MBC1 and MCF-7 ( $<<0.05)$ (Figure 6).

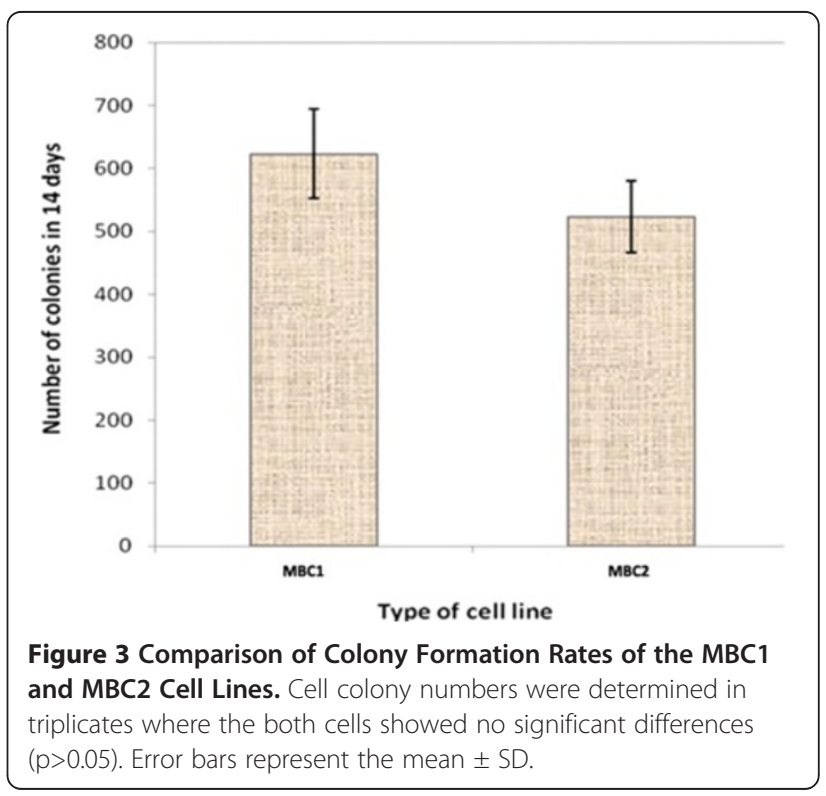




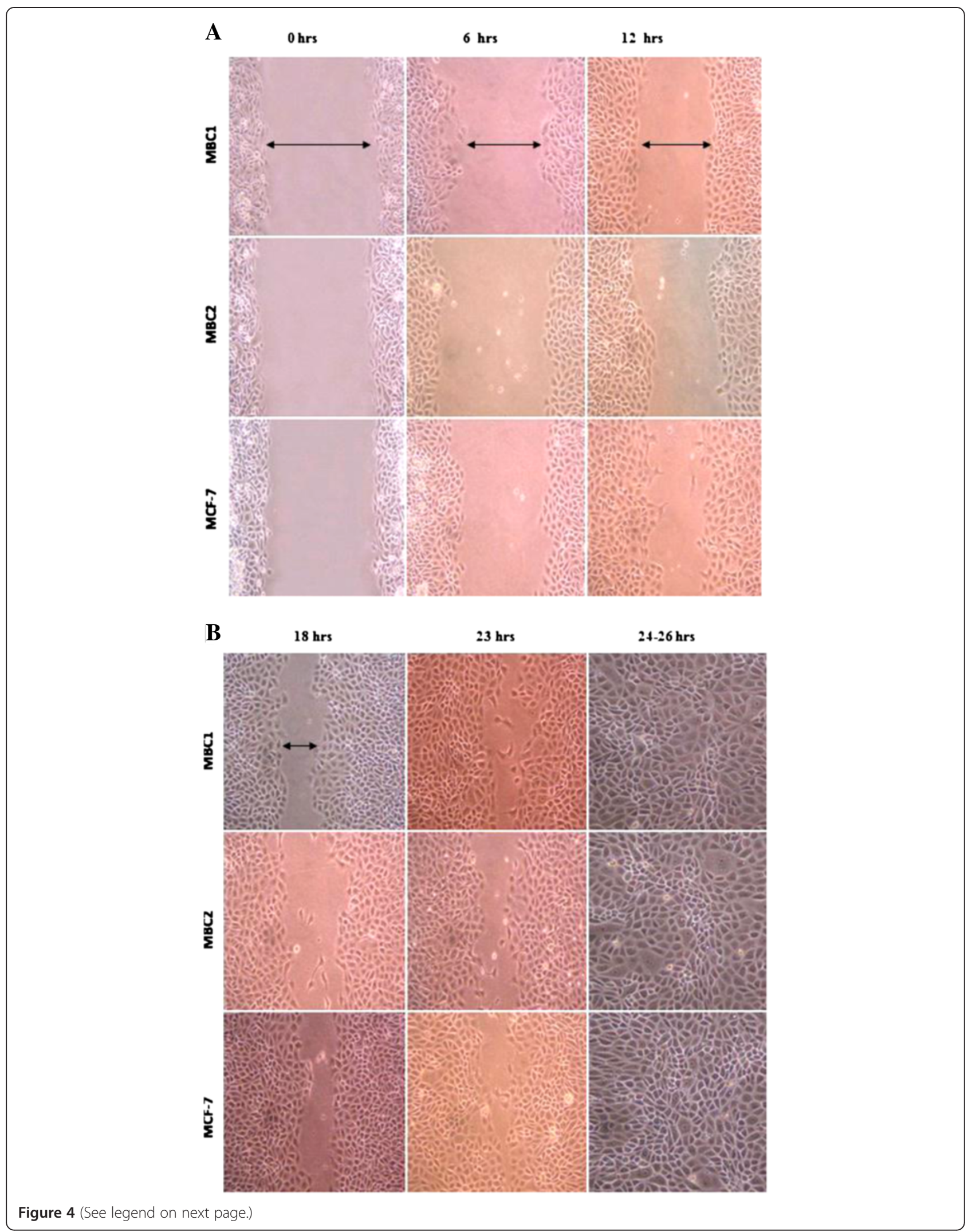


(See figure on previous page.)

Figure 4 A: Wound Healing Assay of the MBC1, MBC2 and MCF-7 Cell Lines at 0, 6 and 12 hrs of Culturing. The result of growth rates in wound healing assays increased in the order of $\mathrm{MBC2}<\mathrm{MBC1}<\mathrm{MCF}-7$, respectively. Magnification, 40X. B: Wound Healing Assay of the MBC1 and MBC2 Cell Lines at 18, 23 and 24-26 hrs of Culture. The result of growth rates in wound healing assays increased in the order of MBC2 < MBC1 < MCF-7, respectively. Magnification, 40X.

\section{Population doubling time (PDT)}

The growth kinetics and the corresponding doubling time at $0,24,48$ and 72 hrs of incubation for the $\mathrm{MBC} 1$ and $\mathrm{MBC} 2$ cell lines were determined at passage 30 . The PDT of the MBC1 and MBC2 were $30.14 \mathrm{hrs}$ and $35.6 \mathrm{hrs}$. The growth rate coefficients for the $\mathrm{MBC} 1$ and $\mathrm{MBC} 2$, representing the number of doublings per unit of time, were $0.023(2.3 \%)$ and $0.0195 \quad(1.95 \%)$, respectively (Figures 7A, B).

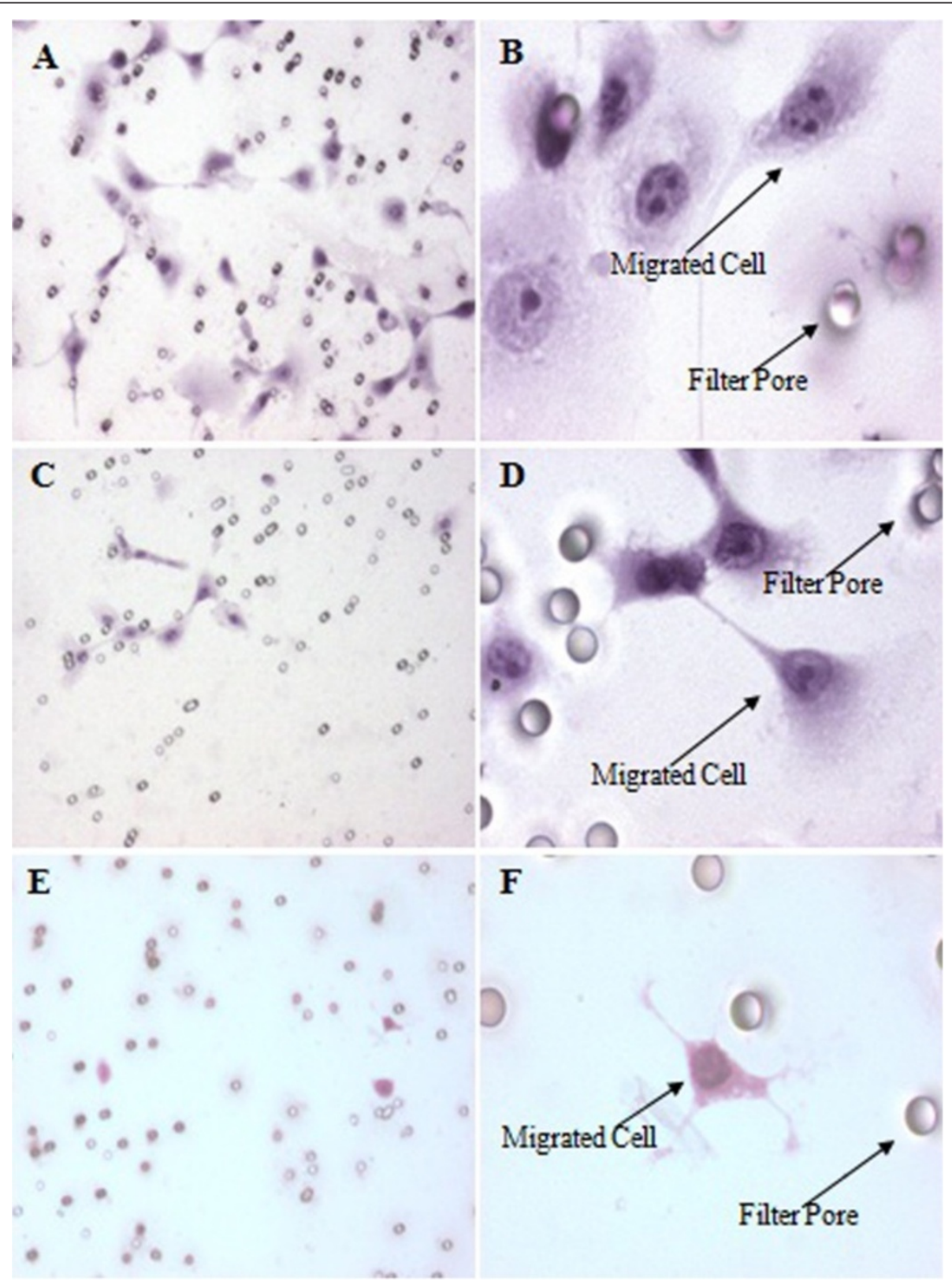

Figure 5 Matrigel Invasion Assay of MBC1 and MBC2 Cell Lines as Compared to MCF-7. Panels (A) and (B) show the invasion activity of MBC1, and panels (C) and (D) indicate the invasion activity of MBC2. Panels $(\mathbf{E})$ and (F) demonstrate the invasion activity of MCF-7 as positive control. Magnification of panels $\mathbf{A}, \mathbf{C} \& \mathbf{E}$ is $10 \mathrm{X} ; \mathbf{B}, \mathbf{D} \& \mathbf{F}$ is $40 \mathrm{X}$. 


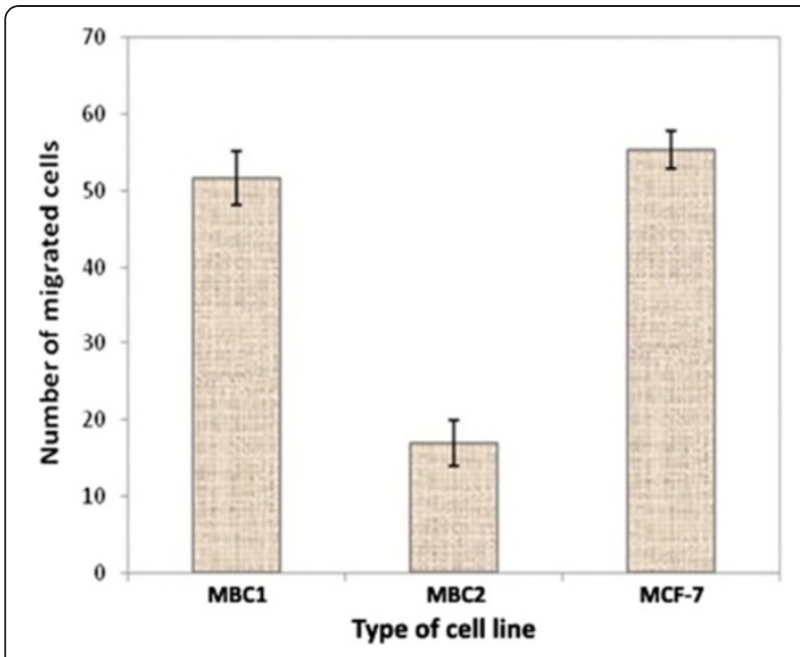

Figure 6 Invasion Rates of the MBC1 and MBC2 Cell Lines as Compared with MCF-7. Error bars indicate mean \pm SD.

\section{DNA-profiling and amelogenin}

DNA profiling using STR markers and Amelogenin of the cells were visualized on $10 \%$ polyacrylamide gels using silver staining method (Figure 8). The PCR product sizes were determined using Labworks software (UVP). No amplification was observed for the D3S1358, D5S818 and D13S317 loci in the MBC1 cells on polyacrylamide gel electrophoresis (PAGE), while all loci were amplified in the MBC2 cell line (Table 1).

\section{Western blotting}

ER expression was detected in the MBC1 and MBC2 cells and MCF-7 (as positive control). No band was observed for the MDA-MB-231(as negative control). Immunoblotting indicated the expression of $\mathrm{PR}$ for the $\mathrm{MBC} 1$ cells, but not expressed for the $\mathrm{MBC} 2$, while both $\mathrm{MBC} 1$ and $\mathrm{MBC} 2$ were positive for the expression of HER2. All cell lines expressed clear and distinct bands of $\beta$-actin, indicating the integrity of the assay (Figure 9).

\section{Fluorescence immunocytochemistry}

Fluorescence ICC shows the presence of ER in the MBC1, MBC2 and MCF-7 as localised nuclear staining pattern. ICC/IF analysis also revealed the expression of progesterone receptors (PR) in the MBC1 and MCF-7 cells with the same localised pattern. However, the $\mathrm{MBC} 2$ cell line was shown to be PR negative compared to MCF-7. The expression of HER2 receptor was further observed by fluorescence ICC in the cell membrane of the MBC1, MBC2 and MDA-MB-453 cell lines (Figures 10, $11,12)$.

\section{Cell cycle analysis}

The number of the MBC1 cells showed an increase in the S-phase on the FCM histogram. The proliferation indices (P.I.) of the MBC1 cell line (P.I. 0.61) was approximately two times higher than the MBC2 (P.I. 0.32), indicating a more proliferative phenotype in the $\mathrm{MBC} 1$ cell line than MBC2 (Figure 13, Table 2).

\section{Cytogenetic analysis}

The G-banding karyotype of the metaphase spread was carried out. Karyotype analysis of the cells with the different cell passages revealed structural and numerical chromosomal abnormalities with chromosome numbers of 46 to 90, in which the majorities show a range of chromosomes between 52 to 58 including several unidentified chromosomes (Figure 14).

\section{Discussion}

Both $\mathrm{MBC} 1$ and $\mathrm{MBC} 2$ are the first breast cancer cell lines established from Malaysian primary breast cancer tissues through spontaneous immortalization. The established cell lines grow as monolayers, adherent with consistent morphologically during subsequent cultures up to 150 passages, without any changes in the epithelial morphology such as MCF-7 and MDA-MB-231. According to data on other human primary cells, the senescence period of cells undergoing cycle arrest varies from 1 to 8 weeks [11]. However, both MBC1 and MBC2 cell lines bypassed this critical phase spontaneously after 4-5 weeks.

The MBC1 and MBC2 cell lines were able to grow in a defined DMEM medium [12] without any extra essential components, elements, or hormones. This is in contrast to for example, MCF-10A cell line requiring cholera toxin; MCF-7 and T-47D needing bovine insulin; and MDA-MB-435S needing ATCC-formulated Leibovitz's L-15 Medium with bovine insulin and glutathione for growth $[7,9,13,14]$.

The more established breast cancer cell lines such as MDA-MB-231 and MCF-7 were derived from malignant effusions [15] which may genetically differ from the original tumour $[16,17]$. However, the breast cancer cells, $\mathrm{MBC} 1$ and $\mathrm{MBC} 2$, were derived from primary infiltrating ductal breast tumours, the most frequently observed histological type [18]. Cells derived from primary breast tumours have a lower chance of establishment compared to cell lines derived from metastatic sites or pleural effusion [13].

The PDT of the MBC1 cells (30.14 hrs) is comparable with the established Italian BRC-230 breast cancer cell line [19] and French human breast cell line VHB-1 [20] with the PDT of 30.5 and $30 \mathrm{hrs}$, respectively; while the PDT of MBC2 (35.6 hrs) is similar to the Chinese BC019, BC-020 breast cancer cell lines with the PDT of 36 hrs and 35 hrs, respectively [21]. The PDT of MBC1 and $\mathrm{MBC} 2$ is higher than the Italian breast cancer cell lines MAST, MA2 and MA3 with a PDT of 68,70 and $78 \mathrm{hrs}$ [22]; the human breast cancer cell lines UACC-812 and 


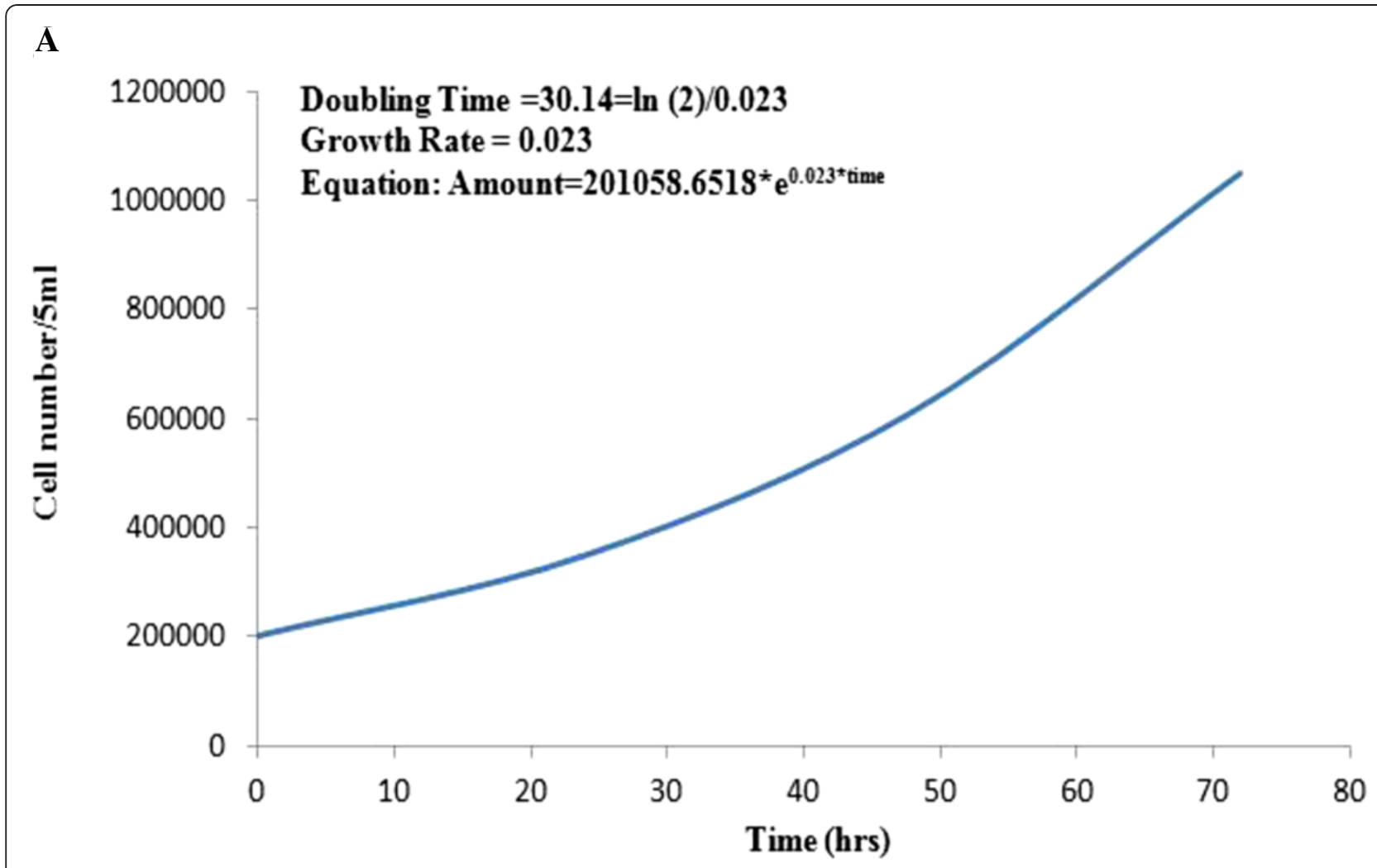

B

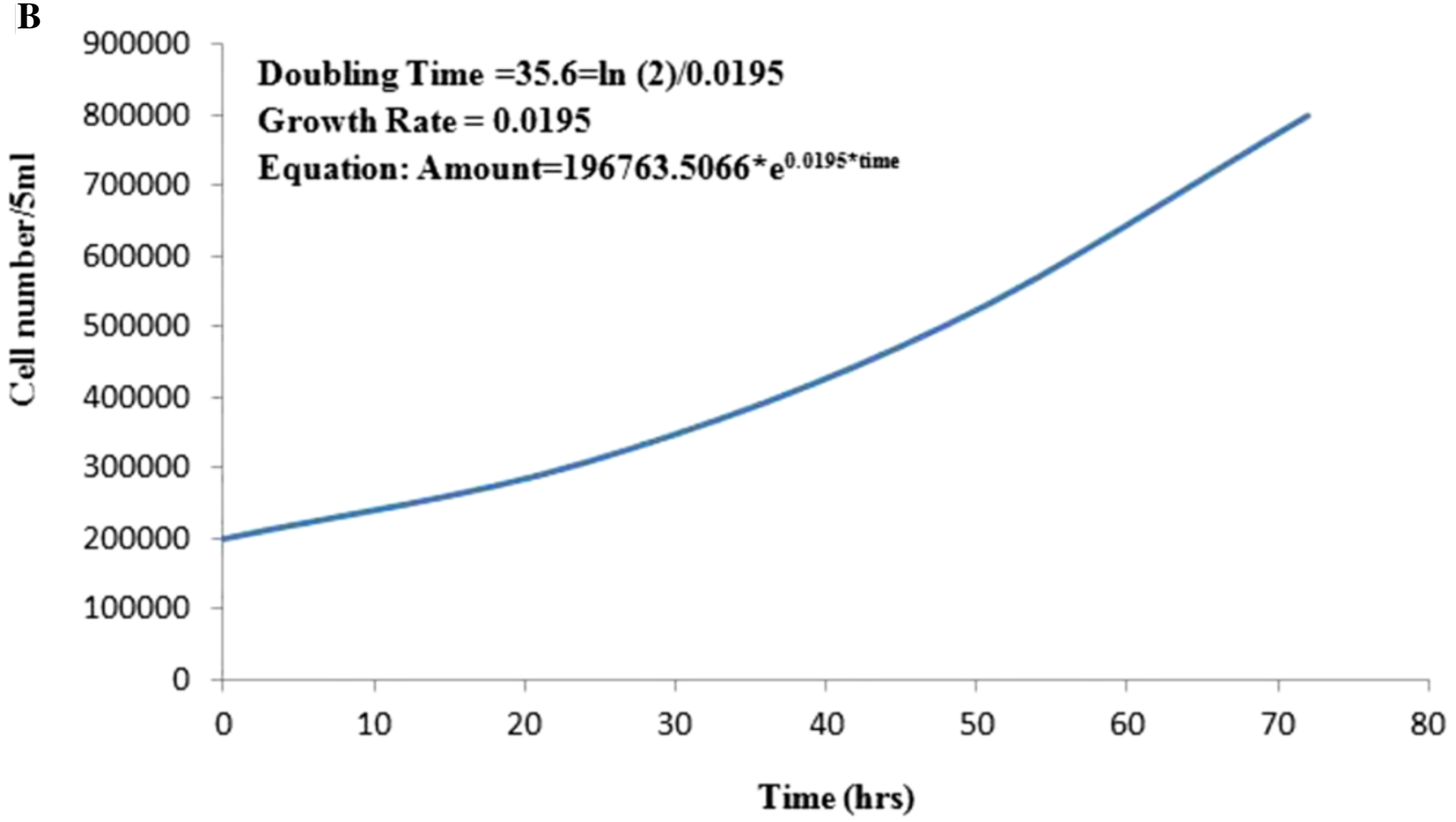

Figure 7 A: Population Doubling Time (PDT) of the MBC1 Cell Lines. Proliferation of the MBC1 was analysed by counting the total cell number at 0, 24, 48 and 72 time points. MBC1 proliferates in vitro with a PDT of 30.14 hours. B: Population Doubling Time (PDT) of the MBC2 Cell Lines. Proliferation of the MBC2 was analysed by counting the total cell number at $0,24,48$ and 72 time points. MBC2 proliferates in vitro with a PDT of 35.6 hours. 

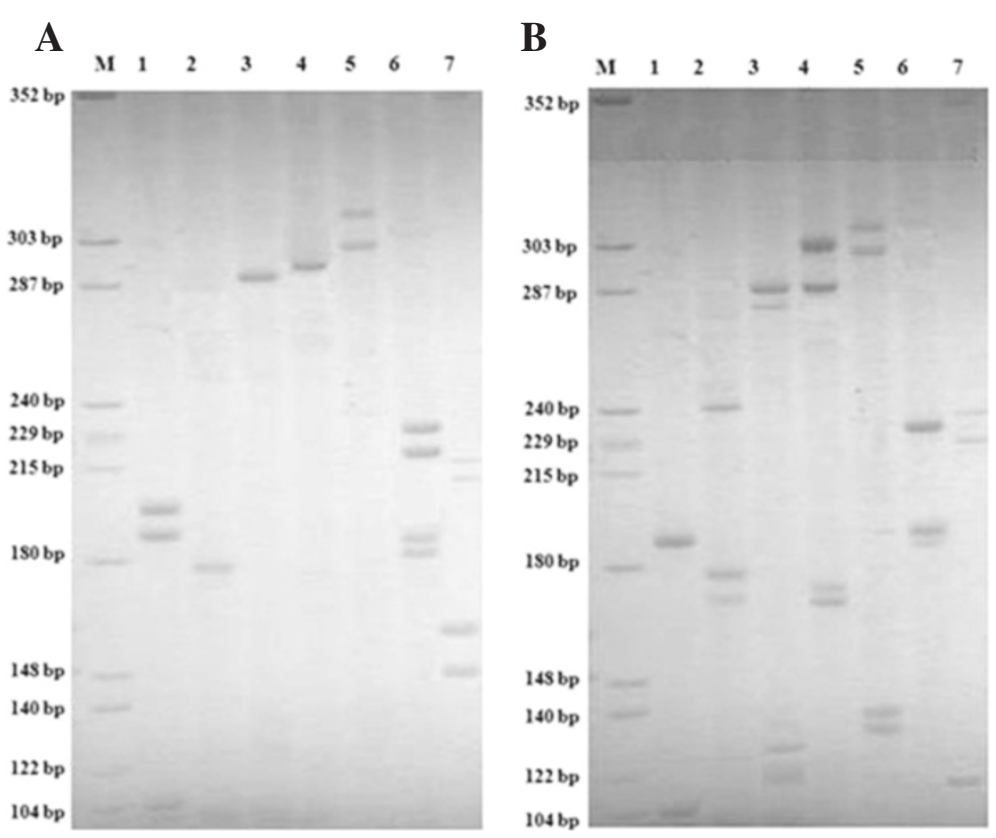

Figure 8 Polyacrylamide Gel Electrophoresis of 13 CODIS STR Loci and Amelogenin for the MBC1 (Panel A) and MBC2 (Panel B) Cell Lines. (Panel A): M: DNA molecular size marker. Lanes 1:[Amelogenin (106 bp), FGA (185 bp, 193 bp)], 2:[D8S1179 (165 bp)], 3:[D16S539 (290 bp)], 4:[D18S51 (292 bp)], 5:[CSF1PO (304 bp, 324 bp)], 6:[TH01 (181 bp, 185 bp), TPOX (225 bp, 236 bp)], and 7:[VWA (145 bp, 150 bp), D21S11 (213bp, 218 bp)]. (Panel B): M: DNA molecular size marker. Lanes 1:[Amelogenin(106 bp), FGA(190 bp)], 2:[D8S1179 (171 bp, 179 bp), D7S820 (239 bp)], 3 : [D3S1358 (122 bp, 124 bp), D16S539 (284 bp, 291 bp)], 4:[D13S317 (169 bp, 173 bp), D18S51(289 bp, 304 bp)], 5:[D5S818 (133bp, 139 bp), CSF1PO (302 bp, 310 bp)], 6:[TH01 (189 bp, 193 bp), TPOX (232 bp], and 7:[WWA (122 bp), D21S11 (228 bp, 240 bp)].

UACC-893 [23] with a doubling time of $100 \mathrm{hrs}$; the cell lines ZR-75-1, ZR-75-27, and ZR-75-30 from the malignant effusions of breast cancer with PDT of 80 hrs, $144 \mathrm{hrs}$ and $110 \mathrm{hrs}$, respectively [24]. According to the results obtained by other researchers, one of the

Table 1 Allele assignment analysis of the amplified STR Loci and Amelogenin for the MBC1 and MBC2 Cell Lines

\begin{tabular}{lll}
\hline STR locus & MBC1 & MBC2 \\
\hline CSF1PO & 10,15 & 9,11 \\
FGA & 19,21 & 20 \\
TH01 & 4,5 & 6,7 \\
TPOX & 6,9 & 8 \\
WWA & 15,17 & 10 \\
D3S1358 & $-{ }^{+}$ & 14,17 \\
D5S818 & $-{ }^{+}$ & 10,11 \\
D7S820 & 13 & 11 \\
D8S1179 & 9 & 10,12 \\
D13S317 & $-{ }^{\dagger}$ & 8,9 \\
D16S539 & 12 & 9,11 \\
D18S51 & 14 & 13,17 \\
D21S11 & 26,27 & 30,33 \\
AMEL & $X, X$ & $X, X$ \\
\hline
\end{tabular}

${ }^{\dagger}$ No STR loci identified for the MBC1 cells. main reasons for the different PDTs of cell lines is the differences in cellular content rather than differences in the rates of proliferation [25]. The enhancement of the population doubling in vitro in the $\mathrm{MBC} 1$ and $\mathrm{MBC} 2$ human breast cell lines may be due to the existence and activity of tumourigenic stem cells [26] or most likely arises from the selection of faster-growing subclones from an initially heterogeneous population through frequent and incomplete trypsinisation of the cultures [27].

Both $\mathrm{MBC} 1$ and $\mathrm{MBC} 2$ cell lines produced a colony size of approximately $95-110 \mu \mathrm{m}$ in diameter after day 14 on soft agar. Depending on the cell line and incubation time, different colony sizes have been reported. For instances, MCF-7 cell line forms 75-100 $\mu \mathrm{m}$ colonies after 11 days of growth and 100-200 $\mu \mathrm{m}$ in diameter by 21 days; T-47D cells form well-defined colonies with diameters of $80 \mu \mathrm{m}$ by day 14 and $120 \mu \mathrm{m}$ by day 21; MaTu cells grow well in soft agar with colony sizes of $50-75 \mu \mathrm{m}$ diameters and sometimes greater than $100 \mu \mathrm{m}$ diameters; MT-1 cells grow rapidly into colonies typically $70 \mu \mathrm{m}$ in diameter by 11 days. However, some cell lines such as MT-3 and HS578T do not grow well in soft agar and therefore form only small colonies in the plate while some others like MC4000 cells produced no colony growth in soft agar [25]. 


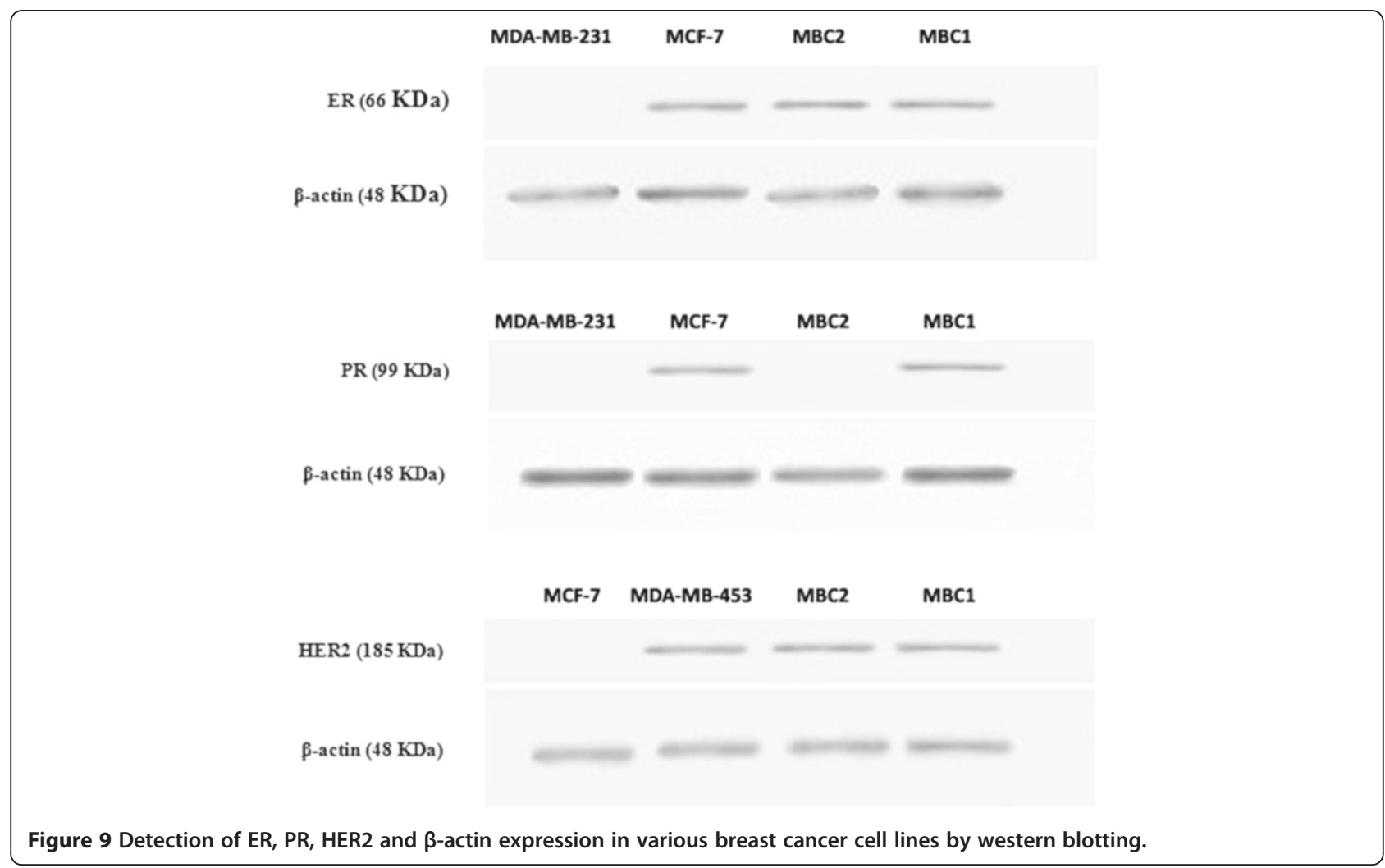

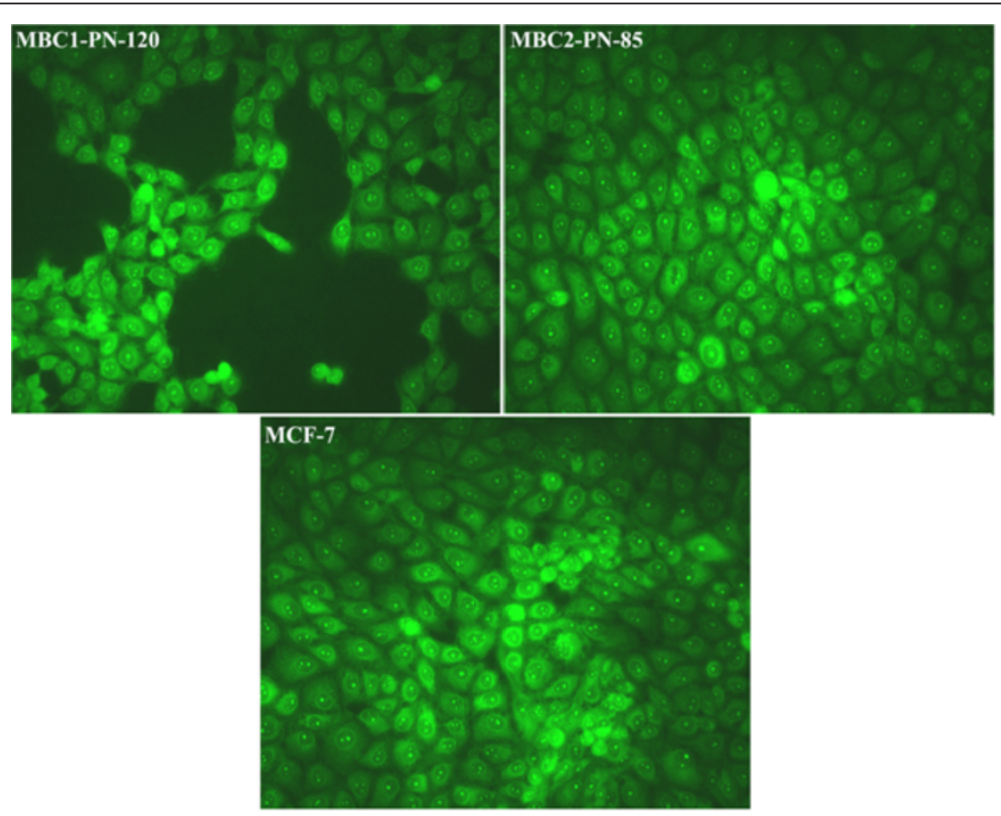

Figure 10 Expression of ER in MBC1 and MBC2 Cell Lines, with MCF-7 as a Positive Control. The expression of ER was shown in the MBC1PN-120, MBC2-PN-85 and MCF-7 (as a positive control) with a localised nuclear staining pattern. Magnification, 20X. 


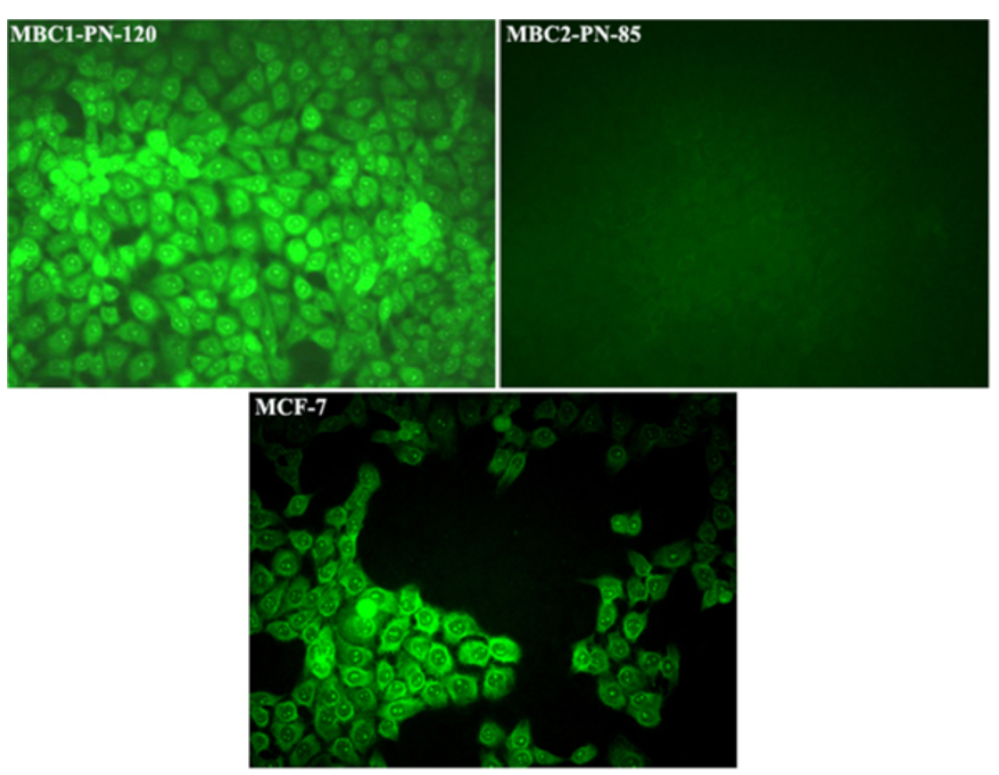

Figure 11 Expression of PR in MBC1 and MBC2 Cell Lines, with MCF-7 as a Positive Control. ICC/IF showed the expression of PR receptor with a localised nuclear staining pattern in the MBC1-PN-120 and MCF-7(as a positive control) but not in MBC2-PN-85. Magnification, 20X.

Wound healing assay showed lower growth rate of the $\mathrm{MBC} 2$ cells compared to the MBC1 and MCF-7 as a control. The MBC1 cell line had similar growth rates with the control cell line MCF-7 in wound healing assay.

The results of entire 13 CODIS core STR loci were compared with the well-characterised and validated references provided by ATCC and JCRB, and those previously reported [10]. The two established cell lines have neither homology to each other nor with other STR-profiled breast cell lines, demonstrating the lack of any cross-contamination of cell lines with other studied cell lines such as MCF-7 [7], MDA-MB-231 [28], HeLa, HepG2, KB and MRC-5 [10]. DNA profiling using STR markers also confirmed the gender of tumour origin of $\mathrm{MBC} 1$ and $\mathrm{MBC} 2$ cell lines.

Expression studies revealed remarkable expression of HER2 protein in both established cell lines. The MBC1
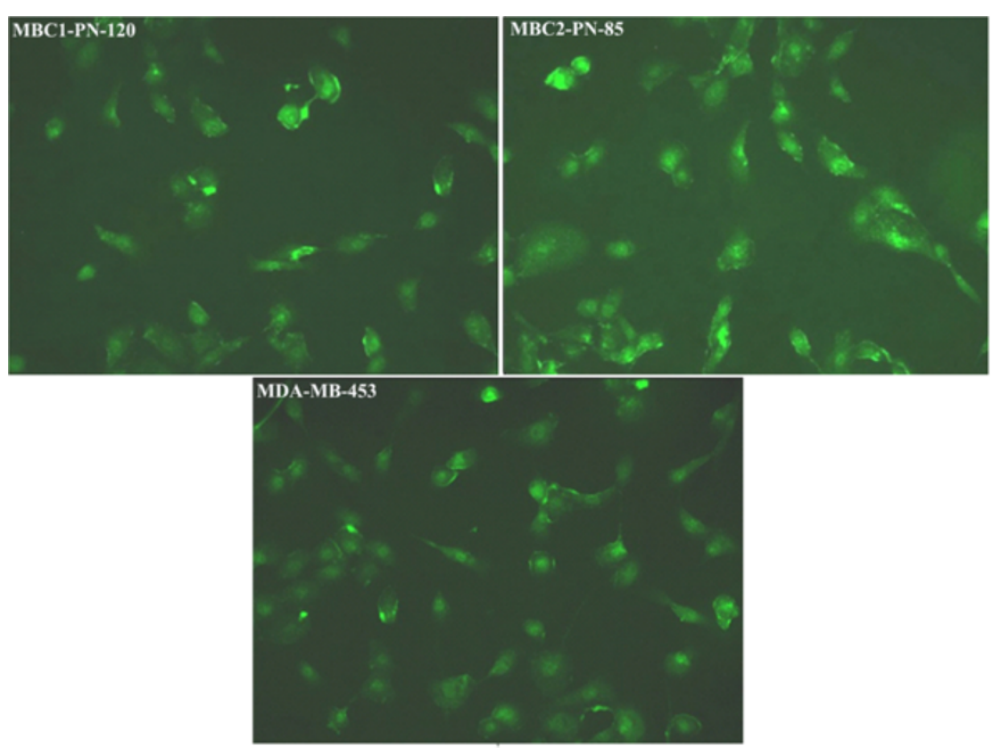

Figure 12 Expression of HER2 in MBC1 and MBC2 Cell Lines, with MDA-MB-453 as a Positive Control. The expression of HER2 with a localised staining pattern in the cell membranes was shown in the MBC1-PN-120, MBC2-PN-85 and MDA-MB-453(as a positive control). Magnification, 20X. 

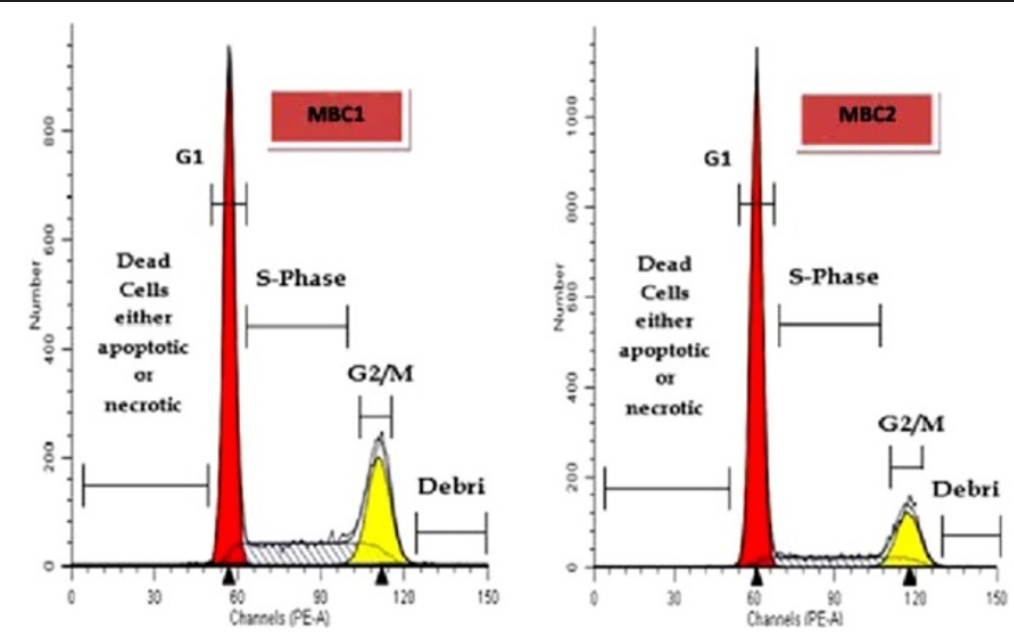

Figure 13 Cell Cycle Analysis of the MBC1 and MBC2 Cell Lines by Flow Cytometry Histogram. Enhancement in the S-phase fraction (SPF) demonstrates an unusual activity level of MBC1 proliferation compared to MBC2.

cell line was also shown to be $\mathrm{ER}^{+} / \mathrm{PR}^{+}$while the $\mathrm{MBC} 2$ was $\mathrm{ER}^{+} / \mathrm{PR}^{-}$based on mRNA expression profiling. However, the tumour origins were shown $\mathrm{ER}^{-} / \mathrm{PR}^{-} / \mathrm{HER} 2^{-}$and $\mathrm{ER}^{-} / \mathrm{PR}^{-} / \mathrm{HER} 2^{+}$for the $\mathrm{MBC} 1$ and $\mathrm{MBC} 2$ cells, respectively. This may be due to a gain in secondary properties after culturing or that the $\mathrm{MBC} 1$ and $\mathrm{MBC} 2$ cells were derived from a small minority of $\mathrm{ER}^{+} / \mathrm{PR}^{+} / \mathrm{HER}^{+}$and $\mathrm{ER}^{+} / \mathrm{PR}^{-} / \mathrm{HER} 2^{+}$cells, respectively. The mechanism of this gain or loss during carcinogenesis is largely unknown but a very feasible hypothesis suggests a possible relationship between such deregulation and specific genetic changes [29].

Hence, these changes could be attributed to the Warburg effect, defined as an increased dependence on glycolysis for ATP synthesis, even in the presence of abundant oxygen, instead of a cell using the more effective pathway of OXPHOS [30]. The Warburg effect has been consistently observed in a wide spectrum of human cancers, and has been directly linked to the activation of oncogenes, and loss of tumor suppressor genes, which result in the deregulated conversion of glucose to lactate. Among the possible mechanisms, mitochondrial malfunction and hypoxia in the tumor microenvironment are considered two major factors contributing to the Warburg effect $[31,32]$.
The MBC1 and $\mathrm{MBC} 2$ cells showed an SPF of $30.12 \%$ and $16.76 \%$ with proliferation index (PI) of 0.61 and 0.32 , respectively, indicating a proportion of $\mathrm{MBC} 2$ cells were arrested in the G0/G1 phase, delaying the progression of the cell cycle and inhibiting cell proliferation compared to the MBC1.

The karyology study of the $\mathrm{MBC} 1$ and $\mathrm{MBC} 2$ cells demonstrated hyperdiploidy and complex rearrangement of their chromosomes. The fractured chromosomes were observed in different numbers in the $\mathrm{MBC} 1$ and $\mathrm{MBC} 2$. The hyperdiploidy (> 50 chromosomes) may arise from the fracture of the chromosomes. Cytogenetic analysis of $\mathrm{MBC} 1$ and $\mathrm{MBC} 2$ revealed an extensively rearranged hyperdiploid karyotype with unidentified chromosomes and a modal chromosome number of 52-58.

\section{Conclusions}

Receptor changes may be due to loss or gain in secondary properties, activation of cancer stem cells and unknown specific genetic changes in tumoral cells. Regardless of receptor status, we hypothesize that, among heterogenous tumoral cells, only cells with low energy metabolism might survive and adjust easily to in vitro conditions. This is to date the first isolation and establishment of immortalised Malaysian primary breast cancer cell lines. Breast

Table 2 Comparison of DNA ploidy and cell cycle measurements of the MBC1 and MBC2 cell lines

\begin{tabular}{|c|c|c|c|c|}
\hline & \multicolumn{2}{|c|}{ MBC1 } & \multicolumn{2}{|c|}{ MBC2 } \\
\hline & Diploid & Tetraploid & Diploid & Tetraploid \\
\hline & $(83.68 \%)$ & $(16.32 \%)$ & $(92.68 \%)$ & $(7.32 \%)$ \\
\hline G0/G1 & $61.88 \%$ & $\% 100$ & $75.24 \%$ & $100 \%$ \\
\hline$S$ & $30.12 \%$ & $\% 0$ & $16.76 \%$ & $0 \%$ \\
\hline G2/M & $8 \%$ & $\% 0$ & $8 \%$ & $0 \%$ \\
\hline Proliferation Index (P.I.) & 0.61 & & 0.32 & \\
\hline
\end{tabular}




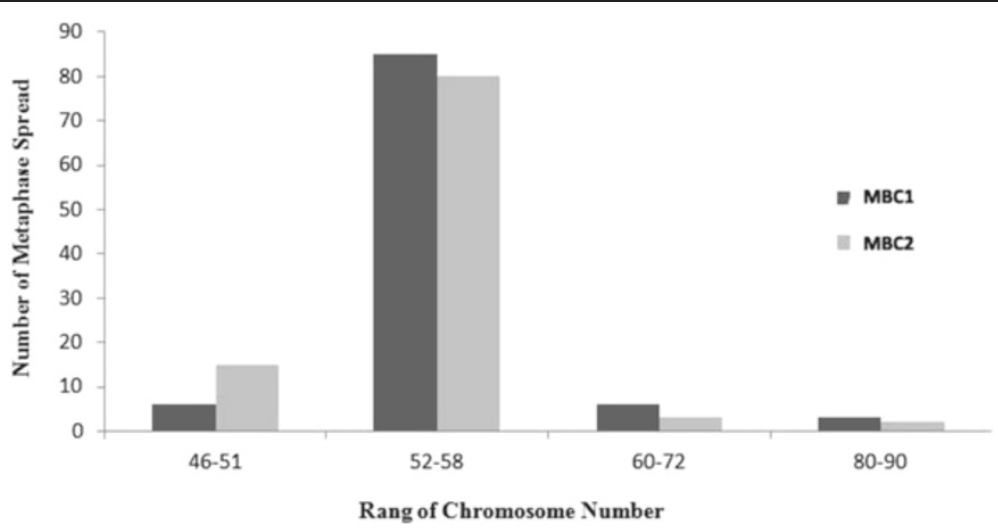

Figure 14 Chromosomal Distribution Pattern of the MBC1 and MBC2 Cell Lines in 100 Metaphase Spreads. A high percentage of the metaphase spreads showed chromosome numbers ranging from 52-58 in both MBC1 and MBC2 cell lines.

cancer cell lines which are currently used are mostly derived from the Caucasian population. The accessibility of two newly established human breast cell lines, MBC1 and $\mathrm{MBC} 2$, could provide us the important tools and new experimental models to study the gene expression patterns, efficacy of therapeutic drugs and prognostic and diagnostic markers, pathogenic mechanisms and biological behaviour of breast cancer in vitro and in vivo. These cell lines could also provide the groundwork to further investigate the activity of new antitumour agents in mono- or polychemotherapy in vitro or to elucidate the mechanisms of drug resistance in breast cancers in the future. They also would serve as prototype models of Malaysian breast carcinogenesis.

\section{Abbreviations \\ ER: Estrogen receptor; PR: Progesterone receptor; HER2/neu: Human epidermal growth factor receptor 2; PDT: Population doubling time; FBS: Fetal bovine serum; RT: Room temperature; CE: Cloning efficiency; SDS-PAGE: Sodium dodecyl sulfate polyacrylamide gel electrophoresis; ATCC: American type culture collection; P.I: Proliferation index; SPF: S-phase fraction; DMEM: Dulbecco's modified eagle medium; PBS: Phosphate buffered saline; STR: Short tandem repeat; CODIS: Combined DNA index system; ICC: Immunocytochemistry.}

\section{Competing interests}

The authors declare that they have no competing interests.

\section{Authors' contributions}

BK carried out the experimental procedures and wrote the manuscript. RR conceived the project and supervised the study. FK and SA participated in the karyotyping and DNA profiling studies, respectively. NJ performed the statistical analysis. MH edited and revised the manuscript. SNA coordinated the collection of two invasive ductal breast carcinoma tissues of the patients and histopathological study. All authors read and approved the final manuscript.

\section{Acknowledgements}

This work was supported by funding from the Ministry of Science, Technology and Innovation, Malaysia (Grant No. 09-02-02-009 BTK/ER/37/6) and a Graduate Student Fellowship from Universiti Putra Malaysia (UPM) awarded to Behnam Kamalidehghan.

\section{Author details}

${ }^{1}$ Genetic Medicine Research Centre, Faculty of Medicine and Health Sciences, Universiti Putra Malaysia UPM Serdang, Selangor 43400, Malaysia.
${ }^{2}$ Department of Pharmacy, Faculty of Medicine, University of Malaya, 50603 Kuala Lumpur, Malaysia. ${ }^{3}$ Department of Medical Genetics, National Institute of Genetic Engineering and Biotechnology (NIGEB), Tehran, Iran. ${ }^{4}$ Genetics Department, Special Medical Center, Tehran, Iran. ${ }^{5}$ Pazhohan Teb Co Ltd, Karaj, Tehran, Iran. ${ }^{6}$ National Cell Bank of Iran, Pasteur Institute of Iran, Tehran, Iran. ${ }^{7}$ Department of Molecular Medicine, School of Advanced Technology of Medical Sciences, Golestan University of Medical Science, Gorgan, Iran. ${ }^{8}$ Department of Pathology, Faculty of Medicine, Universiti Kebangsaan Malaysia, Jalan Yaacob Latif Cheras, Kuala Lumpur 56000, Malaysia. 9UPM-MAKNA Cancer Research Laboratory, Institute of Bioscience, Universiti Putra Malaysia UPM Serdang, Selangor 43400, Malaysia.

Received: 14 August 2012 Accepted: 17 October 2012 Published: 29 October 2012

\section{References}

1. Zimonjic D, Brooks MW, Popescu N, Weinberg RA, Hahn WC: Derivation of human tumor cells in vitro without widespread genomic instability. Cancer Res 2001, 61(24):8838.

2. Hisham A, Yip C: Overview of breast cancer in Malaysian women: a problem with late diagnosis. Asian J Surg 2004, 27(2):130-133.

3. Hisham A, Yip C: Spectrum of breast cancer in Malaysian women: overview. World journal of surgery 2003, 27(8):921-923.

4. Correa C, Bertollo C, Goes A: Establishment and characterization of macl-1 and mgso-3 cell lines derived from human primary breast cancer. Oncology Research Featuring Preclinical and Clinical Cancer Therapeutics 2009, 17(10):473-482.

5. Burdall $\mathrm{S}$, Hanby $A$, Lansdown $M$, Speirs V: Breast cancer cell lines: friend or foe? Breast Cancer Research 2003, 5(2):89-89.

6. Osborne C, Hobbs K, Trent J: Biological differences among MCF-7 human breast cancer cell lines from different laboratories. Breast Cancer Res Treat 1987, 9(2):111-121.

7. Soule H, Vazguez J, Long A, Albert S, Brennan M: A human cell line from a pleural effusion derived from a breast carcinoma. J Natl Cancer Inst 1973, 51(5):1409.

8. Engel LW, Young NA: Human breast carcinoma cells in continuous culture: a review. Cancer Res 1978, 38(11 Part 2):4327.

9. Keydar I, Chen L, Karby S, Weiss F, Delarea J, Radu M, Chaitcik S, Brenner H: Establishment and characterization of a cell line of human breast carcinoma origin. Eur J Cancer 1979, 15(5):659-670.

10. Azari S, Ahmadi N, Tehrani M, Shokri F: Profiling and authentication of human cell lines using short tandem repeat (STR) loci: Report from the National Cell Bank of Iran. Biologicals 2007, 35(3):195-202.

11. Lloyd A: Limits to lifespan. Nature Cell Biology 2002, 4(2):E25-E27.

12. Dulbecco R, Freeman G: Plaque production by the polyoma virus. Virology 1959, 8(3):396.

13. Cailleau R, Olivé M, Cruciger Q: Long-term human breast carcinoma cell lines of metastatic origin: preliminary characterization. In Vitro Cellular \& Developmental Biology-Plant 1978, 14(11):911-915. 
14. Band V, Zajchowski D, Swisshelm K, Trask D, Kulesa V, Cohen C, Connolly J, Sager R: Tumor progression in four mammary epithelial cell lines derived from the same patient. Cancer Res 1990, 50(22):7351.

15. Minafra S, Morello V, Glorioso F, La Fiura A, Tomasino R, Feo S, Mclntosh D, Woolley D: A new cell line (8701-BC) from primary ductal infiltrating carcinoma of human breast. Br J Cancer 1989, 60(2):185.

16. Fogh J: Human tumor lines for cancer research. Cancer Investigation 1986, 4(2):157-184.

17. Pettengill O, Lewko W: Cell culture of human metastatic breast carcinomas: a review. Molecular Biotherapy 1989, 1(3):122.

18. Vijver M: Molecular genetic changes in human breast cancer. Adv Cancer Res 1993, 61:25-56.

19. Amadori D, Bertoni L, Flamigni A, Savini S, Giovanni C, Casanova S, Paola F Amadori A, Giulotto E, Zoli W: Establishment and characterization of a new cell line from primary human breast carcinoma. Breast Cancer Res Treat 1993, 28(3):251-260

20. Vandewalle B, D'Hooghe M, Savary J, Vilain M, Peyrat J, Deminatti M, Delobelle-Deroide A, Lefebvre J: Establishment and characterization of a new cell line (VHB-1) derived from a primary breast carcinoma. J Cancer Res Clin Oncol 1987, 113(6):550-558

21. Shen C, Gu M, Liang D, Miao L, Hu L, Zheng C, Chen J: Establishment and characterization of three new human breast cancer cell lines derived from Chinese breast cancer tissues. Cancer Cell International 2009, 9(1):2.

22. Zoli W, Roncuzzi L, Flamigni A, Gruppioni R, Sensi A, Zini N, Amadori D, Gasperi-Campani A: A new cell line from human infiltrating ductal carcinoma of the breast: establishment and characterization. J Cancer Res Clin Oncol 1996, 122(4):237-242.

23. Meltzer P, Leibovitz A, Dalton W, Villar H, Kute T, Davis J, Nagle R, Trent J: Establishment of two new cell lines derived from human breast carcinomas with HER-2/neu amplification. Br J Cancer 1991, 63(5):727.

24. Engel L, Young N, Tralka T, Lippman M, O'Brien S, Joyce M: Establishment and characterization of three new continuous cell lines derived from human breast carcinomas. Cancer Res 1978, 38(10):3352.

25. Hambly R, Double J, Thompson M, Bibby M: Establishment and characterisation of new cell lines from human breast tumours initially established as tumour xenografts in NMRI nude mice. Breast Cancer Res Treat 1997, 43(3):247-258

26. Han J, Crowe D: Tumor initiating cancer stem cells from human breast cancer cell lines. Int J Oncol 2009, 34(5):1449.

27. Reile H, Birnböck H, Bernhardt G, Spruß T, Schönenberger H: Computerized determination of growth kinetic curves and doubling times from cells in microculture. Anal Biochem 1990, 187(2):262-267.

28. Cailleau R, Young R, Olive M, Reeves W Jr: Breast tumor cell lines from pleural effusions. J Natl Cancer Inst 1974, 53(3):661.

29. Ito I, Yoshimoto M, Iwase T, Watanabe S, Katagiri T, Harada Y, Kasumi F, Yasuda S, Mitomi T, Emi M: Association of genetic alterations on chromosome 17 and loss of hormone receptors in breast cancer. $\mathrm{Br} J$ Cancer 1995, 71(3):438.

30. Warburg O: On respiratory impairment in cancer cells. Science 1956, 124(3215):269-270.

31. Vander Heiden MG, Cantley LC, Thompson CB: Understanding the Warburg effect: the metabolic requirements of cell proliferation. Science's STKE 2009, 324(5930):1029.

32. Kroemer G, Pouyssegur J: Tumor cell metabolism: cancer's Achilles' heel. Cancer Cell 2008, 13(6):472-482

doi:10.1186/1475-2867-12-43

Cite this article as: Kamalidehghan et al:: Establishment and characterization of two human breast carcinoma cell lines by spontaneous immortalization: Discordance between Estrogen, Progesterone and HER2/neu receptors of breast carcinoma tissues with derived cell lines. Cancer Cell International 2012 12:43.

\section{Submit your next manuscript to BioMed Central and take full advantage of:}

- Convenient online submission

- Thorough peer review

- No space constraints or color figure charges

- Immediate publication on acceptance

- Inclusion in PubMed, CAS, Scopus and Google Scholar

- Research which is freely available for redistribution

Submit your manuscript at www.biomedcentral.com/submit
Biomed Central 